\title{
THE TRADITIONS OF THE GEOGRAPHICAL RESEARCH 25 Years of the Geographical Institute of the Czechoslovak Academy of Sciences
}

The scientific research in Czechoslovakia has old traditions although they differ in individual scientific branches. In this place let us mention the Charles University founded in 1348, the oldest university in central, northern and eastern Europe and the Czech Royal Learned Society with its more than 200 years of existence; or the Czech and Slovak Academy of Arts and Sciences whose activity has been continued by the Czechoslovak and Slovak Academies of Sciences.

Similarly, the modern geography including cartography, has its own traditions. In the past it was tought at universities, in cartographic, statistical, town planning and similar institutions and within the scope of the Czechoslovak Geographical Society, founded as early as 1894. Also the „State Map Collection“ has proved its scientific character. It was founded in 1920 as a department of the Geographical Institute of the Charles University, and was controlled by Prof. Václav Švambera up to 1935. At the present time it has amalgamated with the Geographical Institute of the Czechoslovak Academy of Sciences as a separate unit, being the oldest academic workplace in geographv.

The Czechoslovak Academy of Sciences associates as its members the most distinguished scientists from different branches. In its academic institutes theoretical as well as applied research has been pursuit. The academy was founded in 1952 and among its 92 Academicians and Corresponding Members were also four geographers: the Academician Viktor Dvorský (geography, economic geography) and the Corresponding Members Václav Dědina (geography, regional geography), František Vitásek (geography, physical geography) and Josef Kunský (geography, geomorphology). At first seven academic institutes with more than 1100 employees formed the basis of the Crechoslovak Academy of Sciences. Most of the present academic institutes were attached to them in the course of 3-4 years, or at least foundations were laid to their future existence in the form of small institutes, laboratories and independent departments of larger institutes. At that time, i. e. at the beginning of 1954, also four independent geographical departments originated with a promising prospect of a future amalgamation into one geographical institute. In Brno, the Corresponding Member F. Vitásek was head of a department of geomorphology concerned especially with the karst investigation. In Prague the following independent departments came 
into being: the department of historical geography headed by Professor B. Horák, the department of cartography headed by Professor Karel Kuchař and the department of economic geography headed by the nestor of the Czechoslovak geography Professor Jan Hromádka. Their common project was before all the compilation of a new national atlas.

Complications marred the hopeful perspective of a united geographical institute within the Czechoslovak Academy of Sciences, and pushed its off foundation for almost a decade. After longlasting endeavours, the new Geographical Institute was founded on January 1, 1963 and the geographical research in the Academy started to develop according to an unified conception. The dream of Czech geographers to have a research centre in the Czech lands was fulfilled. The programme of the institute is to develop scientific research and, at the same time, to secure an up-to-date service to meet the growing needs of the society. The institute originated by the amalgamation of several smaller departments concerned with special geographical branches and obtained in this way a highly trained staff. On the other hand, this fusion resulted in a certain unbalance in the representation of individual geographical branches, weakening in this way the complexity of the geographical research.

The research programme of the new institute, apart from geomorphology and karst investigation. economic geography and cartography, was soon enriched by biogeography, climatology, hydrology, human geography, regional geography of Czechoslovakia as well as of the developing countries, and the thematic cartography in connection with an intense start on the compilation of the national atlas, an important unifying element of the whole Czechoslovak geography and cartography.

In the course of its existence. the new institute has included individual departments representing the basic geographical branches, such as the department of phvsical geography, human geography, regional geography and cartography. Apart from this basic structure, different new departments originate according to the needs of new research programmes. A special nosition among the above disciplines is invariably occupied by the karst research.

The Geographical Institute of the Czechoslovak Academy of Sciences has applied the results and experiences of those institutes of which it was formed. and has achieved after a short time of its existence some remarkable theoretical as well as practical and scientific-organizational successes. Compared with institutes abroad. it ranks next to the most developed non-university geographical institutes in Poland, USSR, Hungary. FRG or GDR with which it has an intense scientific cooperation. The favourable development is reflected in an expanded cooperation with socialist countries as well as with the International Geographical Union, especially in its working grouns, such as the Commission of the Slope Development. Commission of National Atlases. Commission on Methods of Economic Regionalization, of Applied Geography, e. a. The institute was entrusted with the coordination of the research in the developing countries in the sphere of geology, geography and mining. Its research workers following up with the programmes of the United $\mathrm{Na}$ tions Organization have studied such nroblems as ..The Develonment of Tourism in Tunisia“, ..Geogranhical Monographv of Ghana" (40), or „The Economic Exploitation of Karst Areas for the National Economy 
of Cuba". Apart from many different research programmes, the institute - from the very beginning of its existence - has been mainly concerned with a complex geographical research of Czechoslovakia.

The basic scientific problem in which the institute had cooperated with Slovak geographers for almost two decades was "The Geographical Regionalization in Czechoslovakia". It should have characterized the system and types of geographical units, and show the relationships between the natural environment and the economic exploitation and settlement in the landscape $(36,42)$. Prior to the foundation of the institute, the results achieved by Czechoslovak geographers were appreciated at home as well as abroad. A stimulus came from the scientific workers of the institute to establish an international I. G. U. commission on methods of economic regionalization (18). Some works on the regionalization were applied in the reconstruction of the settlement structure in Czechoslovakia, for the purposes of regional planning and also in the territorial-administrative reform started in 1960. Its fundamental regional aim was to form new administrative areas to conform with the newly formed large economic regions (30).

The Geographical Institute succeeded in elaborating and publishing the Atlas of the Czechoslovak Socialist Republic (1) which includes 400 maps with the legend in three languages. It shows the physical-geographical and human-geographical conditions of the country. The work and the responsibility for the compilation of most of the maps was gradually taken over by the staff of the Geographical Institute of the Czechoslovak and Slovak Academy of Sciences.

An essential part of the work of physical geographers was concentrated for a long time on the elaboration of a complex physical-geographical regionalization of the territory of Bohemia and Moravia. It consisted in the construction of geomorphological, climatic, hydrological, pedological and biogeographical maps of the whole territory on the scale of $1: 200000$. Then comprehensive thematic maps of relevent features were made, and finally the definite map of the physical geographical division of CSR on the scale of 1 : 500 000. An extensive monography called „River Terraces in Czech Lands“ (4) was published, and preparations were made for detailed and comprehensive synoptical geomorphological mapping. The conception of comprehensive mapping became the basis for the legend of the ..International Geomorphological Map of Europe". On the basis of maior observations carried out in the Moravian Karst, a new conception of its geomorphological development - using the results of the present speleogeomorphology - came into being. A complex investigation of the newly discovered Amateur Cave has shown that the cave could be used for speleotherapeutical purposes.

In climatology and hydrologv was important the elaboration of mesoclimatic characteristics and relationships between climatic elements and the oscilations of the underground water level as a basis for the prognosis of changes in the reserves of the underground water. To meet the requirements of the regional planning, the mesoclimate in $840 \mathrm{Czech}$ and Slovak settlements with more than 2000 inhabitants was studied (25). Apart from the pedological regionalization of the area of CSR, the problem of vertical soil zonality was tackled as well as the problems of its anthropogenous transformations. The soil erosion was studied and the term "potential soil erosion" was then applied in the space eva- 
luation of this phenomenon called „Potential Soil Erosion by Flowing Water in the Area of CSR" (28). The publication „The Development of Soil Erosion in ČSR " (29) gives the prognosis of conditions and development of this phenomenon up to 2000. Biogeographers elaborated an original approach to biogeographical maps in a geobiocenological conception (7). Informations obtained through this method enabled the compilation of maps of the ecological stability of the landscape, providing the basis for the protection and planning of the natural environment.

From the beginning of the sixties, geographers became interested in the geography of population and settlement, in connection with the requirements of the transformation of the urban settlement system in Czechoslovakia (32). Geographers tried to come up with the answers to demographic problems of urban as well as non-urban population, such as daily commuting (17), migration, age structure, etc. The morphometric typology of country settlements had been studied earlier, for the last time in 1956 (14), therefore the new institute paid more attention to the problem of the urban settlement systems. Apart from the functional classification and typology, the location of towns from the viewpoint of the housing construction (15) including the capital Prague (41) was evaluated. According to international standards "The Population Map of Czechoslovakia" has been compiled (27). An extensive geographical research of settlement agglomerations in the whole republic has achieved considerable results $(5)$.

In the course of the 19th century industry developed on a wide scale on the whole territory of Czechoslovakia influencing the landscape. The industrial relations became the subject of study of the geography of industry. In the Czechoslovak Academy of Sciences especially problems associated with the geographical classification, structure and measurement of the industrial volume $(20,31,34)$, industrial agglomerations and especially the relationships between industrial centres and settlements have been studied. The development of industrial enterprises is closely related to the housing construction, increasing the number of town inhabitants. Similarly, commuting to work increases, especially in places of a larger concentration of industry (relatively more in smaller than in larger towns). Therefore in a complex evaluation of regional importance of towns, the coeficient of commutation can easily be misleading unless completed with other coeficients.

Although the branch of the geography of agriculture could follow up with the results achieved previously, it was developing only at a slow pace. Similarly, also the method of land-use started asserting itself as late as 1965. Up to the present time it has achieved good results [11]. Studies of the soil erosion are of a great importance for agriculture. To meet the requirements of modern geography, the scientific staff of the institute was rebuild approximatly till the end of the sixties, refining the exploration techniques to secure an equal representation in individual scientific branches.

The sixties may be considered the most fruitful era of geography and cartography in the Czechoslovakia. Apart from the above-mentioned national atlas, was produced a „Czechoslovak military atlas" (8, 38) which appeared in two editions. "Other extensive regional works originated also at that time, such as the study „Příbor-Koprivnice- 
-Štramberk" (13) or "The Complex Geographical Investigation of the Area of Dams on the Dyje near Nové Mlýny" (10). In this place let us also mention the "Regional Structure of Czechoslovakia" (33) as well as the "Geography of Czechoslovakia" (9). The study of evaluation methods of positive and negative influences of economic activities upon the geographical environment $[22,39]$ formed the basis of future research programme.

The main aim of the research, the study of the geographical regionalization, continued arosing interest in the relevant applications of the results. For some time it was supervised by the Presidium of the Czechoslovak Academy of Sciences. Informations obtained through different analyses applied in individual research spheres (industry, agriculture, population, etc.) were published in a different ways. A collection of papers was issued called "Methods of Economic Geographical Regionalization" (19). In 1969-1972 branch regionalizations in CSR were finished by the research team of the institute. They arosed considerable interest and some of them appeared in the form of books $[12,16,21$, 23). The achieved results have partly been illustrated on maps [1 : : 500000 ) in the form of a „Collection of Maps of the Physical-Geographical Rayonization of CSR" and a "Collection of Maps of Economic-Geographical Regionalization of CSR". Together with a map illustrating the quality of the living environment, 17 such thematic maps of the territory of CSR have been published.*

The work on complex regionalization, especially the economic-geographical collection, was overdue because of its complexity and other problems. The most convenient for our territory seemed to be the conception of "nodal regions", based on the fact that the population concentrated in urban settlements is the deciding factor in the production, and at the same time, a mass consumer of goods and services, which forms the basic space relations in the landscape. It enable the division of the area of CSR according to a uniform system of coeficients, even if their interpretation is far from being perfect disregarding the results of the physical-geographical and other regionalizations of the area under study. In the determination of spheres of influence in the neighbourhood of settlements and of the hierarchical degree of regional integrity, often only the mobility of population (commutation, migration, etc.) became the main indicator, and not further, for instance, the economic structure of the area.

The final result of the regionalization of the area of CSR should have been the map of the "Economic-Geographical Regions in CSR" and a corresponding study published in 1977 (6). More valuable was the work "Microregionalization of CSR" finished in 1974 as a result of delineating geographical units at a lower hierarchical level. Its practical goal was to contribute - at the suggestion of the Czech Planning Committee - to the evaluation of work of regional and district national committees, which resulted in defining the local population centres in future settlement systems.

*) The main results achieved in the investigations of the geographical regionalization in Slovakia were used in the elaboration of the Atlas of the Slovak Socialist Republic (Bratislava, SAV-SÜGK, 1980). 
The hitherto investigations have shown that the territorial aspects of the structural development of the most important factors in the geographical differenciation in the country are predominantly determined by general conditions, especially by the condition of the dynamics of the macro-economic development. This was characteristic of its economy and settlement system up to the second half of the seventies, when the first signs of a transition to a more intense model of development started to appear. At that time, most of the scientific workers of the Geographical Institute bent their effort to studies, such as the "Geographical Potential of the Landscape“, „Socio-Economic Potential of CSR“ and "Modelling of State, Development and Interactions of Factors of the Environment in CSR". They tried to determine the then applied and potential possibilities of capacities in individual areas of the republic. It was also necessary to supply the answer to the problems of service equipment and housing standard in the population centres as well as the evaluation of natural, social and economic conditions of housing, recreation and tourist traffic.

Since the eighties the theoretical preparation has shown the possibilities of the application of research in the regional planning, on the presumption that its efforts would bend in the direction of space organization and a more rational areal administration, which could result in a greater efficiency and marked savings to its sponsors. One of the variants of the planned areas is the delimitation of socio-economic regions by grouping the districts on the basis of a similar structure and integration. On the territory of CSR 27 regions were defined and the possibilities of cooperation and regional specialization were outlined (37). The research of nodal regions has much contributed to the conception of the conversion of the settlement structure in particular areas.

In the seventies the institute concentrated on the problems of the geographical evaluation of the landscape and the living environment which are of an immense importance at the present time. The institute was entrusted with the coordination of the "Quantitative Evaluation of the Present Relief-Forming Processes“. It also cooperated in the „Regional Evaluation and Development of the Sources of the Geosphere". Another pressing problem to be solved was the „System of a Complex Protection of the Natural Environment in the North Bohemian Brown Coal Area and the Neighbouring Districts" which was one of the first suggestions of a more general research of the geographical aspects of the environment. These problems were studied not only in the above-mentioned area but also in model areas of Liberec, Jihlava, Ostrava, Luhačovice, Břeclav and Českomoravská vysočina (Bohemian-Moravian Highland].

A synthetic geographical research of environmental problems was carried out in areas of different size on the whole territory of the republic, for which in cooperation with the Terplan Board an „Ecological Generel of CSR" has been elaborated. The development of interactions of geographical factors of the living environment were studied in selected model areas in North Bohemia and North and South Moravia. The achieved results update and expand the store of knowledge necessary for a qualified forecast of changes in the future development of studied processes and environmental phenomena. The study "Living Environment in Czech Socialist Republic" describes the state, problems 
and perspectives for the needs of the relevant authorities. On the basis of promising results achieved in the country as well as abroad, an international laboratory of the geographical research of environmental problems should be established as part of the Geographical Institute.

The Czechoslovak geographers always have stressed the importance of a map interpretation of individual research stages as well as of its final results. To this aim, at the beginning of the eighties, the institute was quickly equipped with modern instrumentation enabling a faster information processing and automation of cartographic shaping of research results. Since 1981 the institute concentrated on a comprehensive treatment of its main research aim, i. e. "The Earth, Remote Sensing and Cartographic Modelling of the Landscape". To this purpose radio-controlled aeroplane models were used in taking aerial photos of the earth from lower heights. Within the Interkosmos programme, the institute has been gradually equipped with new apparatus for aircraft and satellite scanning for geographical purposes.

The institute has achieved interesting results in the branch of long-distance investigation of the Earth. The results were described in the publication „Methods of Multispectral Aerial Photographing from Lower Heights" and in the catalogue of spectral properties of objects selected for interpretation.

Rich cartographic experiences together with a cartographic laboratory, equipped with the automatic cartographical system DIGIKART, have speeded up the edition of several map collections and atlases, such as the map collection showing the prognosis of selected areal factors of the development of Czechoslovak economy up to the year 2000 (24), the atlas containing the results of the last census of people, houses and flats in CSR in 1980 (3), a collection of maps of the Czechoslovak health-service (26), or the "Atlas of the population of Czechoslovakia“ [2].

In the mid-eighties the geographical research in the Czechoslovak Academy of Sciences gradually took up the theoretical research of regional planning and its application in regional and physical planning of the development of national economy and settlement. A scientific organization of a complex utilization of the territory of Czechoslovakia may result in a rational surmounting of departmental barriers, and a more effective development of individual areas with the preservation and improvement of the living environment. Consequently, the research programme of the Geographical Institute was expanded with targets such as "Geosystem Diagnoses and Prognoses of Environmental Problems and the Research of Geosystems by Methods of Remote Sensing of the Earth" and the "Prognosis of the Regional Development in Czechoslovakia". The main practical aim of the geographical research is to contribute to the reform of the Czechoslovak national economy and the reconstruction of its areal organization. Theoretically, these trends will most probably lead to the improvement of areal specialization and especially regional syntheses of the geographical research.

The rich publication activity of the scientific team of the institute is backed up by its own polygraphic base. Apart from the conventional "Studia Geographica“ and the „Reports from the Geographical Institute of the Czechoslovak Academy of Sciences" another four series of different orientation, and the bibliographic annual „Czechoslovak Geo- 
graphical Bibliography", have been published in cooperation with the Czechoslovak Geographical Society as a result of a continuous bibliographic activity since 1959. The publications are the subject of a book exchange at home as well as abroad. The institute library gets books in exchange from some 250 foreign institutions.

Within the frame of the research programme, some original apparatus and equipment have been developed, for instance, the apparatus for the investigation of the soil erosion and collecting of samples of water-bone material in streams with a turbulent waterflow. For the mapping of the erosion and other phenomena, a radiooperated aeroplane model provided with a multispectral photographic camera was constructed. Scanning apparatus of the above mentioned conception are applied in a great many scientific branches in Czechoslovakia as well as abroad.

The mesoclimate is studied by means of a measuring vehicle provided with special home-constructed measuring apparatus. For application in the mesoclimatic research a three-dimensional field anemograph has been developed used also in meteorological safeguarding of nuclear power stations.

The Institute of Geography cooperates with university geographical departments as well as with prominent geographers in different state institutions. In future, the main aim of the research work will include the intesification of the theoretical system of geography and the inter-communication of special developing geographical disciplines within the frame of complex regional relationships of natural and social factors. The most important practical application of the research activity of the institute may be expected in the sphere of regional planning and organization, and in the preservation of the natural environment of the Czech landscape.

\section{Liter a ture:}

1. Atlas Československé socialistické republiky. 58 mapových listů s texty. Praha, ČSAV-ÚSGK 1966.

2. Atlas obyvatelstva ČSSR. Brno, GGÚ ČSAV-FSÚ 1988.

3. Atlas ze sčítání lidu, domů a bytů 1980. Česká socialistická republika, $1: 500000$. Brno, GGÚ ČSAV-ČSÚ 1984, $30 \mathrm{mp}$. listů.

4. BALATKA, B., SLĀDEK, J.: Říční terasy v českých zemích. Praha, NČSAV 1962, 580 str.

5. BLAŽEK, M.: Vymezení městských aglomerací v ČSSR. Sborník ČSZ, 67, Praha, NČSAV 1962, č. 3, s. 258-264.

6. BLAŽEK, M. (red.): Ekonomická regionalizace. Studia Geographica 53, Brno, GGÚ ČSAV 1977, 66 str.

7. BUČEK, A., LACINA, J., RAUŠER, J.: Pokroky biogeografie za posledních 30 let. Geografický výzkum v ČSAV. Praha, GGÚ ČSAV 1983, s. 82-87.

8. Československý vojenský atlas. Praha, MNO-C̄SAV 1966, 276 map. listů.

9. DEMEK, J., STR̃IDA, M. et al.: Geography of Czechoslovakia. Praha, Academia 1971, 348 str.

10. Geografický obraz zájmového území u Nových Mlýnů. Brno, GGŪ ČSAV 1967, 223 str.

11. GÖTZ, A.: Geografická rajonizace zemědělské výroby. Studia Geographica 8, Brno, GGÚ ĆSAV 1969, s. 32-39.

12. HORSKY, J.: Regionalizace České socialistické republiky na základě spádu osobní dopravy. Studia Geographica 59, Brno, GGÚ ČSAV 1978, $184 \mathrm{str}$.

13. Komplexní geografický výzkum území Příbor - Kopřivnice - Stramberk. Brno, GGŨ ČSAV 1964, 326 str. 
14. LAÀZNIC̆KA, Z.: Typologie venkovského osídlení Č̉eskoslovenska. Práce brnĕnské základny ČSAV XXVIII, č. 3, Brno 1986.

15. LÁZNIČKA, Z.: Př́spěvek $\mathrm{k}$ charakteristice našich sídel $\mathrm{z}$ hlediska jejich sklonových poměrů a morfometrie polohy. Sborník ČSZ, 67, Praha, NČSAV 1962, č. 4, s. $287-302$.

16. LĀZNIČKA, Z.: Funkční klasifikace obcí ČSR. Praha, Academia 1974.

17. MACKA, M.: K otázce struktury dojiždění do práce. Sborník ČSZ, 67, Praha, NČSAV 1962 , č. 4 , s. $303-324$.

18. MACKA, M. (red.): Economic Regionalization. Praha, Academia 1967, 224 str.

19. MACKA, M. (red.): K metodám ekonomickogeografické regionalizace. Studia Geographica 8, Brno, GGÚ ČSAV 1969, 138 str.

20. MAREŠ, J.: New Method of Regionalizing Manufacturing Industry. Regional Studies. Budapest, Ak. Kiadó 1974, s. 347-365.

21. MAREŠ, J.: Průmyslové regiony ČSR. Rozpravy ČSAV, rada MPV 90/6. Praha, Academia 1980, 82 str.

22. MIKULİK, O.: Geografické hodnocení vlivu člověka na životní prostředí. Brno, GGÚ ČSAV 1980, 190 str.

23. NOVĀKOVĀ, B.: Migrace obyvatelstva $v$ moravských krajích. Praha, Academia 1971.

24. Prognóza vybraných oblastních faktorů rozvoje národního hospodářství v ČSSR do roku 2000. Soubor tematických map 1: 1 mil. Praha, GGU ČSAV-FMHTS 1982, 11 mapových listů.

25. QUITT, E.: Hodnocení mezoklimatických pomèrů sídel nad 2000 obyvatel. Sborník ČSZ, 68, Praha, NČSAV 1963, č. 4, s. 293-316.

26. Soubor map zdravotnictví ČSSR. Praha, GGÚ ČSAV-VÚVTR 1987, 9 mapových listů, $40 \mathrm{~s}$. textu.

27. STÁRKOVĀ, I., VOTRUBEC, C.: Populační mapa ČSSR $1: 1$ mil. Sborník ČSZ, 68, Praha, NČSAV 1963, č. 1, s. 84-86.

28. STEHLIK, O.: Potenciální eroze proudící vodou na území ČSR. Studia Geographica 42, Brno, GGÚ ČSAV 1975, 148 str.

29. STEHLIK, O.: Vývoj eroze v ČSSR. Studia Geographica 72, Brno, GGÚ ČSAV 1981,37 str.

30. STR̃IDA, M.: Práce ČSAV k novému územnímu uspořádání Československa. Věstník ČSAV, 69, 1960, č. 3 , s. 552-562.

31. STR̂́DA, M.: Průmyslová jádra. Sborník ČSZ, 67, Praha, NČSAV 1962, č. 2, s. 143 až 152.

32. STR̃IDA, M.: K otázce struktury osídlení Československa. Sborník ČsZ, 71, 1966, č. 1 , s. $24-41$.

33. STR̃IDA, M. [red.]: Oblastní struktura Československa. Sborník prací. Brno, GGU ČSAV 1967, 112 str.

34. STR̃̃IDA, M.: Průmyslové oblasti a střediska v Čechách. Studia Geographica 8, Brno, GGÚ ČSAV 1969, s. 126-136.

35. STR̃IDA, M. (red.): Geografický výzkum v Československé akademii věd. Sborník referátů. Praha, GGÚ ČSAV 1983, 304 str.

36. Supplement of the Journal of the Czechoslovak Geographical Society. Praha, Academia 1964, 208 str.

37. VITURKA, M.: Aplikace metody hlavních komponent ve vyzkumu diferenciace prostorové socioekonomické struktury ČSR. Studia Geographica 84, Brno, GGÚ ČSAV 1985.

38. Vojenský zeměpisný atlas. Praha, MNO 1975, 448 str.

39. VORĀCEK, V., PREOBRAŽENSKIJ, V.: Hodnocení vlivu hospodářské činnosti na přírodu. Brno, GGÚ ČSAV 1985, 377 str.

40. VOTRUBEC, C.: Ghana, nástin geografické monografie. Praha, GGÚ ČSAV 1965, $320 \mathrm{str}$.

41. VOTRUBEC, C.: Praha - zeměpis velkoměsta. Praha, SPN 1965, 244 str.

42. Institute of Geography of the Czechoslovak Academy of Sciences. Zprávy GGÚ ČSAV, Opava, GGÚ ČSAV 1964, č. 4, s. 1-10. 


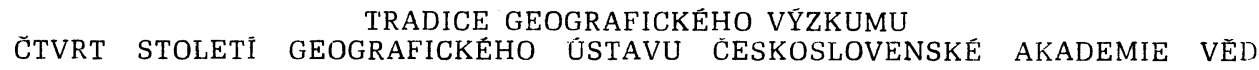

ČSAV byla založena jako vědecká instituce pracovního typu v roce 1952. Mezi jejími 92 členy byli i čtyř̀ geografové: akademik Viktor Dvorský a členové korespondenti Václav Dědina, František Vitásek a Josef Kunský. V letech 1952-1953 byla založena samostatná geografická pracoviště, v Brně Kabinet pro geomorfologii, v Praze pak Kabinet pro historickou geografii, Kabinet pro hospodářskou geografii a Kabinet pro kartografii, do nějž byla začleněna Státní sbírka mapová vzniklá už v roce 1920 jako nejstarší akademické pracoviště. Jednotný Geografický ústav však vznikl z těchto zálkladů až k 1. 1. 1963. Vedle geomorfologie, ekonomické geografie a kartografie byl jeho výzkum brzy rozšiřen o biogeografii, klimatologii a hydrologii, geografii obyvatelstva a sídel, regionální geografii a tematickou kartografii $v$ souvislosti se zahájenim intenzívních prací na Atlase ČSSR, který se stal jednotící silou celé československé geografie a kartografie.

Při plnění různých výzkumných úkolů se jako základní zaměření cinnosti ústavu od začátíu jeví komplexní geografický výzkum území ćSR. Práce na regionalizaci byly zčásti využity při rekonstrukci sídelní struktury Ceskoslovenska, pro oblastní plánování i územně administrativní reformu. V šedesátých letech vrcholilo nejplodnější období geografie v ČSAV. Vedle zmíněného Atlasu ČSSR vznikl i Čs. vojenský atlas, velké regionální studie prostoru Kopřivnice a Dolního Podyjí i reprezentační dilo Goography of Czechoslovakia. Dosažené výsledky se podařilo z velké části dokumentovat $\mathrm{v}$ publikacích i mapách, zejména v souboru fyzickogeografické a ekonomickogeografické regionalizace ČSR v měŕítku 1:500 000 . Práce na souborných regionalizacích, zvláště ekonomickogeografické, se však pro svoji složitost opoždovaly.

$\mathrm{V}$ průběhu sedmdesátých let se začal ústav zaměřovat na úkoly geografického potenciálu krajiny a geografického hodnocení životního prostředí. Metody výzkumu prostř̀edí se řešily $\mathrm{v}$ různě velikých modelových oblastech a spolu $\mathrm{s}$ Terplanem byl vypracován „Ekologický generel ČSR“. Ủstav dospěl i k zajímavým výsledkům v oboru dálkového průzkumu Země a eroze půdy proudící vodou.

Začátkem osmdesátých let se ústav počal rychleji vybavovat moderní přistrojovou technikou, napomáhající zejména zpracování informací a automatizaci kartografického ztvárnění výsledků výzkumu. Později se orientace geografie v ČSAV přesouvá do sféry základního výzkumu pro potřeby oblastního a územního plánování rozvoje národního hospodářství a osídlení.

Rozvinutá publikační činnost se opírá o vlastní polygrafickou základnu. Vedle tradičních řad Studia Geographica a Zprávy GGÚ ČSAV vycházejí ještě čtyři série a bibliografická ročenka Československá geografická literatura, vydávaná spolu s ČSGS. Publikace jsou předmětem mezinárodní výměny zahrnující na 250 institucí.

Ūstav úzce spolupracuije s předními geografickými pracovišti na vysokých školách i s geografy $z$ povolání $v$ různých státních organizacích. $V$ př́ištích letech by se měl zabývat především prohloubením teoretického systému geografie, propojením speciálních geografických disciplín $\mathrm{v}$ rámci komplexních regionálních vztahů přírodní a společenské složky a praktickými aplikacemi na úseku řízení a regionálního plánování i př̀i ochraně a tvorbě životního prostředí krajiny.

(Pracoviště autorů: M. Str̆ída - Geografický ústav ČSAV, Albertov 6, 12843 Praha 2; O. Stehlík - Geografický ústav ČSAV, Mendlovo nám. 1, 66282 Brno.

Došlo do redakce 21. 12. 1987. 


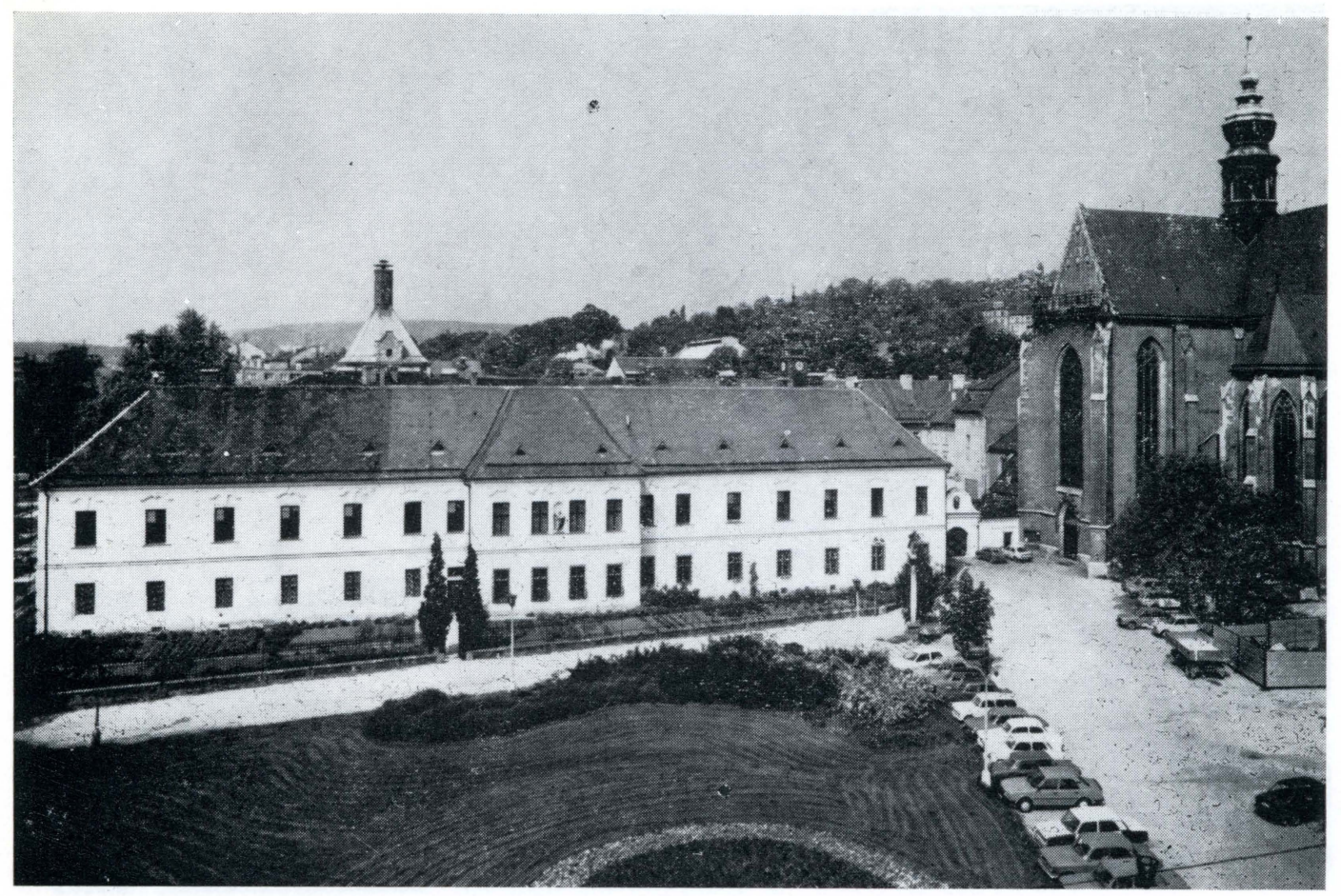

5. Building of the Geographical Institute of the Czechoslovak Academy of Sciences in Brno. 6. An old library in the building of the Geographical Institute.

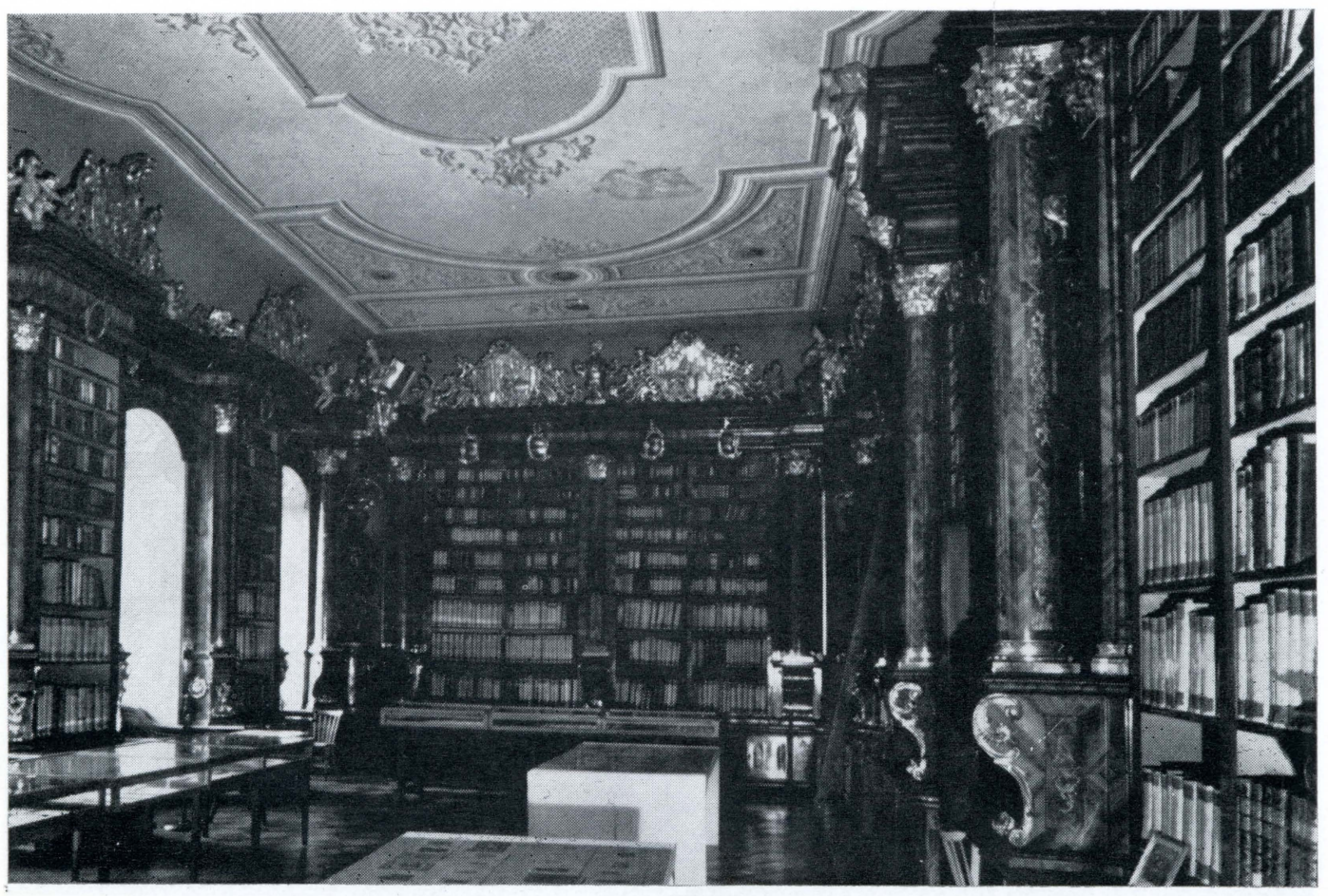




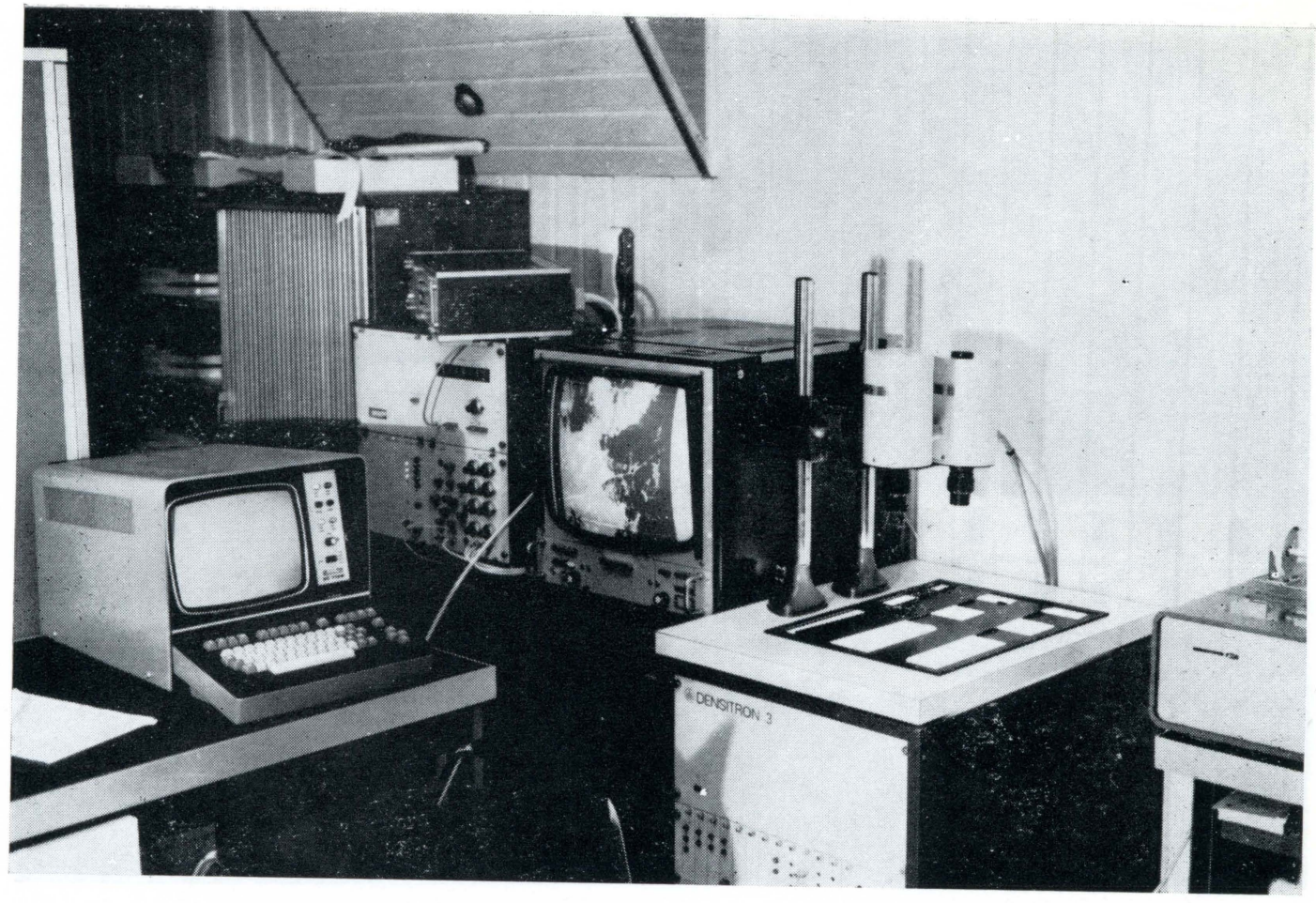

7. A part of the cartographic laboratory.

8. Device for remote sensing from low altitudes made in Geographical Institute.

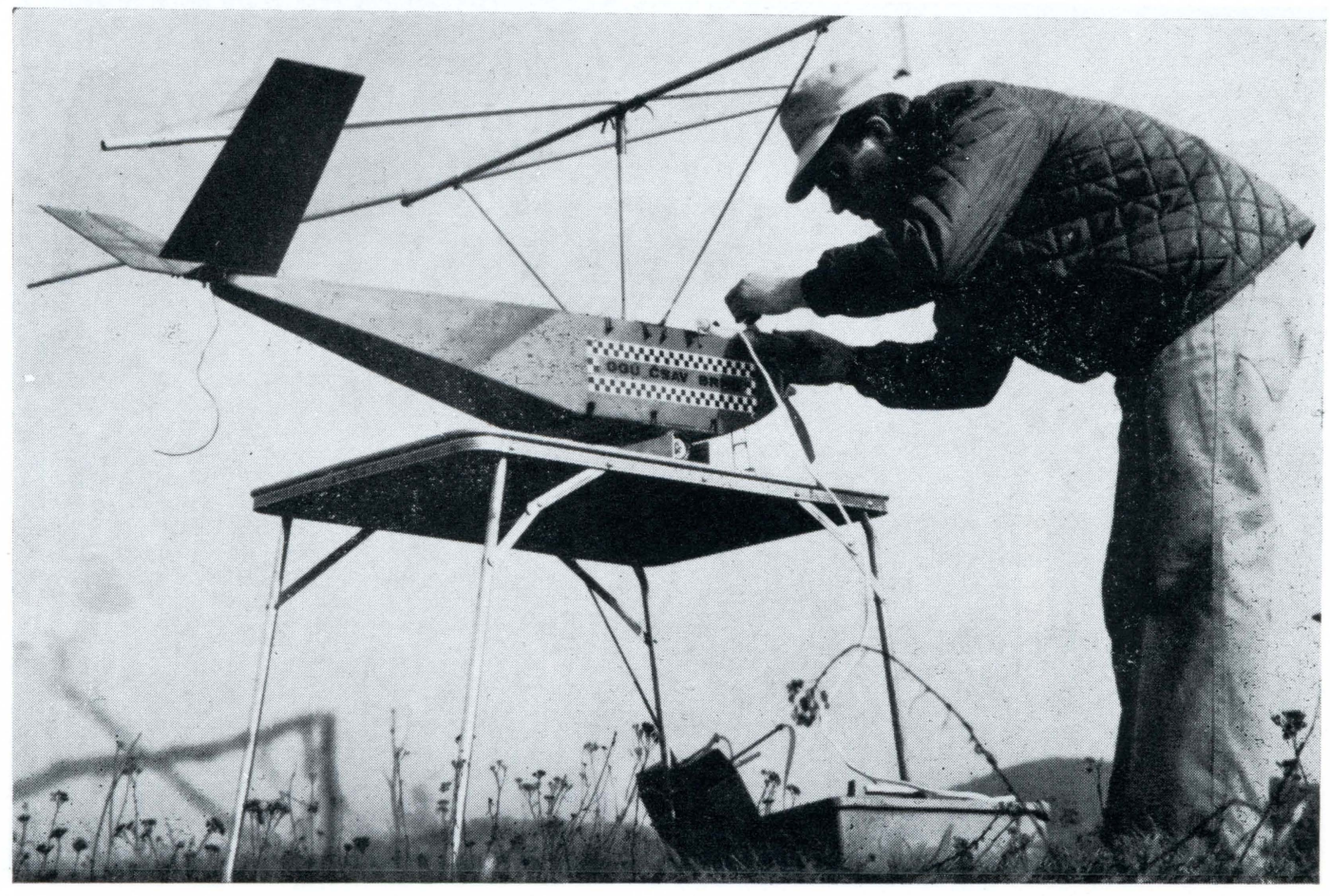




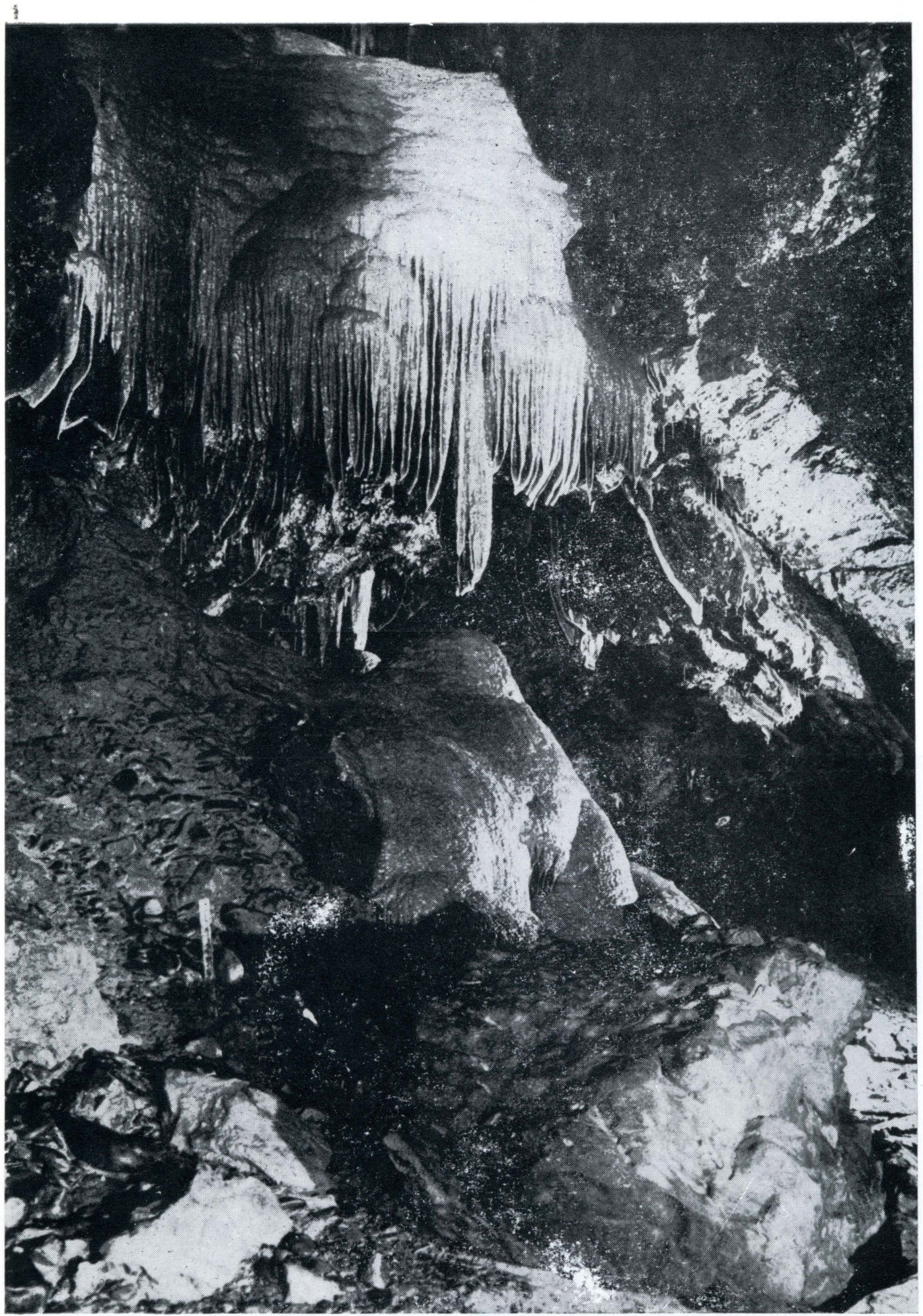

9. A part of the Amateur Cave where scientists of the Geographical institute have made many investigations. Photos J. Keprt. 